\title{
The Economical Use of Water as Affecting the Extent of Rights Under the Doctrine of Prior Appropriation
}

In an article on theories of water law in the Harvard Law Review for April, I9I4, Mr. Samuel C. Wiel distinguishes between the doctrine of prior appropriation of water and the riparian doctrine of correlative rights from the point of view, largely, of social justice. He shows that the strict enforcement of priorities among appropriators of water is a far departure from the original notion that running water is common to all, and how, with full appropriation of any stream, such strict enforcenent of priorities visits the disaster of a water shortage only on the later appropriators, while prior appropriators are enjoying the use of the stream in full measure. He develops the fact that the courts are in some instances modifying the doctrine of prior appropriation to the extent, in times of shortage, of substituting a pro-rating among appropriators for strict enforcement of priorities, thus tending ulitinately to apply among appropriators the coinmon law theory of correlative rights that underlies the division of water among owners of riparian lands.

The accomplishment of a better use of water than originally resulted from a strict enforcement of the law of appropriation seems likely to be aided in another way that is no more abrupt than the one to which attention is called by the author of the paper referred to, viz: through a growing appreciation of the notion of "economical use" of water as distinguished from "beneficial use", which now underlies all appropriation rights. The term "economical use", as used here, and as explained more fully later, is concerned with the quantity of the result obtained from irrigation rather than with only the quality, as in "beneficial use".

While originally the capacity of ditches frequently governed the quantity of water allowed appropriators, ${ }^{2}$ and the putting of water

1 " $\mathrm{He}$ is entitled to the water, so undiminished in quantity, as to leave sufficient to fill his ditch as it existed at the time the locations were made above." The Bear River and Auburn Water and Mining Co. v. The New York Mining Co. (1857), 8 Cal. 327. 
to a beneficial use was not and possibly still is not essential to the acquirement of rights by appropriation, ${ }^{2}$ in most states actual use has been added as an element in the creation of an appropriation right, ${ }^{3}$ and in California the law, in determining the extent of rights, requires use, in accordance with section I4II of the Civil Code, which states that "the appropriation must be for some useful or beneficial purpose." 4 It is not desired here, however, to develop this transition, in California or elsewhere, from the notion that mere possession alone gave an appropriation right to the present notion that use is a necessary element. ${ }^{5}$ But, beginning with the latter notion, it is thought worth while to trace through a few of the decisions those gradual restrictions in the quantity of water allowed that make the ultimate adoption of a rule of economical use, in place of, or at least along with, the present rule of beneficial use, seem reasonable.

Since in early days in the West water was generally sufficient for most of those desiring it, it is only natural that distinctions in the character of use allowable do not generally appear for some years after settlement began, although in early California cases the reasonableness of priorities was taken into consideration. ${ }^{6}$ In a Nevada case decided in 1875,7 we find it stated that "no person

2 Cal. Civ. Code, $\$ 1417$. By "completion" is meant conducting the waters to the place of intended use. "In view of the California code section above quoted $[\S 1417]$, it is difficult to see how it can be denied that the possessory test of completion of the right remains in force in California and that diversion (with a bona fide intention) there completes the right, the question of consummation of the use operating as a matter subsequent, by abandonment or forfeiture of possession." Wiel, Water Rights in the Western States, 3rd ed., p. 432.

3 Wiel, Water Rights in the Western States, 3rd ed., p. 434.

* "This evidence clearly shows that the quantity of water claimed by defendants under the Hines appropriation largely exceeds the quantity put to any useful purpose on the Hines ranch, and therefore exceeds the quantity actually appropriated." Senior v. Anderson (1896), 47 Pac. 454. The test of an appropriator's right to water for irrigation is the amount of water actually used for beneficial purposes as provided by Cal. Civ. Code, $\S 1411$. Trimble v. Heller (1914), 138 Pac. 376. "The effect of the decisions clearly appears to be that one actually diverting water under a claim of appropriation for a useful or beneficial purpose can not by such diversion acquire any right to divert more water than is reasonably necessary for such use or purpose, no matter how long a diversion in excess thereof has continued." Cal. Pastoral and Agr. Co. v.. Medera Canal and Irr. Co. (1914), 138 Pac. 718.

5 For a full discussion of this see Wiel, Water Rights in the Western States, 3rd ed., pp. 428-432.

"Article by Samuel C. Wiel on "Priority" in Western Water Law, 18 Yale Law Rev. 189.

7 Barnes v. Sabron (1875), 10 Nev. 217. 
can by virtue of a prior appropriation claim or hold any more than is necessary for the purpose of the appropriation." In an Idaho case decided in $1892^{8}$ the court went a slight step farther when it said that the amount of water necessary to the proper irrigation of the land in question should be taken into consideration. In 1895 the Nevada court held" that "the first appropriator is only entitled to the water to the extent that he has use for it when economically and reasonably used." In a leading Nevada case decided by the United States Circuit Court in $1897^{10}$ it was stated that "The complainant, as well as the respondents, should be required to make an economic as well as a reasonable use of the water." In an Idaho case of $1909^{11}$ it was held that "The amount of water that a water user and consumer has been in the habit of using and applying to his land can not be accepted as the true test of the duty of water, but the question . . . is the amount actually necessary", and further, that "In determining the duty of water, reference should always be had to lands that have been prepared and reduced to a reasonably good condition for irrigation", and " . . . Water users should not be allowed an excessive quantity of water to compensate for and counterbalance their neglect or indolence in the preparation of their lands for their successful and economical application of the water." A further advanced step was taken by the Oregon court in $1909^{12}$ when it declared that "water must be used in such manner, and such economical methods must be adopted in its application to uses desired as will secure the greatest duty available, even though it becomes necessary to change at considerable expense the old methods." The same court in I $9 I_{I}{ }^{13}$ very much in the same line, declared that the amount of water that may be taken by a prior appropriator for irrigation depends on "the number of acres of such land that is susceptible to cultivation, the degree of sterility of the premises, the most profitable crops that can be raised by artificial application of moisture, and the quantity of water necessary to produce the harvest on an acre by careful husbandry."

8 Kirk et al. v. Bartholomew et al. (1892), 2 Idaho 1087, 29 Pac. 40. 9 Roeder v. Stein (1895), 23 Nev. 92, 42 Pac. 867.

10 Union Mill and Mining Co. v. Dangberg et al. (1897), 81 Fed 73.

11 Farmers' Co-operative Ditch Co. v. Riverside Irrigation Dist., Ltd., et al. (1909), 102 Pac. 481.

12 Hough v. Porter (1909), 98 Pac. 1083.

13 Donnelly et al. v. Cuhna (1911), 61 Ore. 72, 119 Pac. 331.

14 After referring to 102 Pac. 481 quoted from above, the Supreme Court of California in a 1914 case stated: "It was declared in the case 
While numerous decisions can be cited in which this tendency to limit the quantity of water allowable under appropriations is not shown, ${ }^{15}$ the weight of opinion seems to indicate an encouraging progression toward a theory of use that lays less and less stress on exclusive rights of the first appropriators in order to meet the needs of those who come later. Especially does this seem to be brought out in the Idaho and Oregon decisions last cited. It is believed that these decisions rank with the pro-rating discussed in the article referred to in the beginning of this paper in being definite steps in adapting theories of water law to the changing needs of western communities.

Now if the courts are at this time willing to pro-rate among appropriators in times of shortage and to require such use as shall result in the "greatest duty available" and in growing the "most profitable crops", is it not reasonable to expect them ultimately to go farther and to require such use as shall be really economical not alone to the individual, but to society at large?

The idea of the economical use of water in the sense held to in this paper has chiefly become concrete through numerous experiments conducted in the West designed to determine the duty of water for various crops, ${ }^{16}$ although the idea has been generally in

last cited [102 Pac. 481] that it was the policy of the law of the state [Idaho] to require the highest and greatest possible duty from the waters of the state in the interest of agriculture and other useful and beneficial purposes. Such is clearly the policy of the law of this state." Cal. Pastoral and Agr. Co. v. Madera Canal and Irr. Co. (1914), 138 Pac. 718.

15 "Their [old settlers who took advantage of the United States statute of 1866] methods of use have been those which were the least expensive, and, no doubt, to some extent were extravagant, yet they can not be expected to install methods now that might reduce to a minimum the amount of water necessary, at a cost that would absorb the profits." Iittle Walla Irr. Union et al. v. Finis Irr. Co. et a1. (1912), 124 Pac. 666. In determining the amount of water which a user applies to a beneficial use, and to which he is entitied by prior right, the system of irrigation in common use in the locality is to be taken as the standard, though a more economical method might be adopted. Rogers v. Pitt et a1. (1898), 89 Fed. 420. "As appears from the proof, the appellant applied the water to the land in an ordinary and usual way, and he was not bound to furrow his land before irrigation." Nephi Irr. Co. v. Vickers (1905), 81 Pac. 144.

${ }^{16}$ Among the published reports referring to specific experiments along these lines are the following: Report of Irrigation Investigations in Idaho, by Don. H. Bark, printed in Eighth Biennial Report of the State Engineer of Idaho; Report of Irrigation Investigations in California, by Frank Adams, printed in Third Biennial Report of the State Engineer of California; Progress Report of Co-operative Irrigation Experiments at California University Farm, by S. H. Beckett, printed 
the minds of students of irrigation for many years. It is that use of water that returns the largest crop yield per unit of water applied, rather than the largest yields per acre, and it is made important by the operation of what might be termed a law of diminishing return from irrigation water, by which each successive unit of water applied in irrigation in general results in a less increase in crop yield than the unit of water applied just before.

By way of illustrating this term "economical use", as used in this paper, and first citing the California experiments referred to in the footnote, it may be stated that these experiments were made with alfalfa and were designed to aid in ascertaining the proper duty of water for that crop in Sacramento Valley, California. The check plats received no water, while the irrigated plats were given, respectively, I, I.5, 2, 2.5, 3, 4, and 5 acre-feet of water per acre during each of four seasons, in addition to rainfall. The average yields obtamed from these plats during the four seasons were, respectively, 4.55 (with no irrigation water), 5.75, 6.36, 7.39, 8.63, $8.62,8.90$, and 8.90 $0^{17}$ tons per acre. In other words, the first acre-foot of water applied returned I.20 tons of alfalfa, r.5 acre-feet returned I.8I tons, 2 acre-feet returned 2.84 tons, 2.5 acre-feet returned 4.08 tons, 3 acre-feet returned 4.07 tons, and both 4 and 5 acre-feet each returned 4.35 tons. Expressed still differently, the first acre-foot increased the yield I.20 tons, the next one-half acrefoot increased it $0.6 \mathrm{I}$ ton, the next one-half acre-foot increased it I.03 tons, the next one-half acre-foot increased it I.24 tons, the next one-half acre-foot decreased it 0.01 ton, the next acre-foot increased it 0.28 ton, and the fifth acre-foot produced no more than the fourth.

In reporting their Utah experiments, which have dealt with more crops than have the California experiments, Dr. Widtsoe and Professor Merrill express the determmed relations in terms of the crop-producing power of 30 acre-imches, or 2.5 acre-feet, of water when applied to different areas of land. Citing only their results with alfalfa, it is found that this anount of water applied to I acre produced $4.4 \mathrm{I}$ tons, whereas when applied to 2 acres it produced 7.55 tons, and when applied to 3 acres it produced I4.83 tons.

in U. S. Department of Agriculture, Bulletin 10; Reports of Irrigation Investigations in Utah, by John A. Widtsoe and L. A. Merrill, printed in Utah Experiment Station, Bulletins 116, 117, 118.

17 The plats receiving 5 acre-feet per acre Der season have thus far been carried through only two seasons. 
These California and Utah experiments are not cited because they teach students of irrigation what they have not long known in a general way, which they do not, or because they are conclusive as to the quantity of water always best suited to the growth of alfalfa, which they are not, but because they concretely illustrate a principle which seems bound, in increasing measure, to govern the quantities of water to be allowed irrigators under the doctrine of prior appropriation. What is economical for the individual irrigator will depend on the value of his land, the cost of labor and water, the value of his product, etc. For instance, if his production costs are low and his sale prices are high, it may be economical to him individually to apply water up to the inaximum point of production, which may be considerably above the maximum quantity used in either the California or the Utah or the Idaho experiments cited in the text or in the foot-note. But what is economical to the individual will not in time be economical to society at large. which it must be assumed is interested, withm reasonable limits, in the largest aggregate production-the most "economical" use-rather than in the largest production per acre-the most "beneficial" use.

It is interesting to note, as an evidence of the growing importance of specific expression with reference to beneficial and economical use of water, that at a conference of western irrigation engineers and managers held late in $19133^{18}$ an effort was made to define what constitutes both beneficial and economical use of water in irrigation. As the results of this effort occasioned wide coinment among those interested, it is believed the statement adopted at the conference can be profitably included in this paper in full. It is as follows:

66. Beneficial use of water.-A water user with a vested water right limited to beneficial use is entitled to that amount of water that will render him a reasonable inaximum anount of good with a reasonably economic handling of the water. Since he has acquired his vested right from the laws of his state, he is entitled to protection of that right by the state; but it is his duty to the state, and the people of the state have the right to demand of him, that he use every reasonable method to reduce the amount of water required to a miniinum.

18 U. S. Reclamation Service, Notes of Conference of Irrigation Managers in Salt Lake City, Utah, Nov. 12 to 15, 1913 (Discussion "T"). 
67. This demand requires the water user: (a) to make reasonable preparation of the ground surface for irrigation; (b) to use good judgment in selecting appropriate methods of applying the water to the ground; (c) to prepare reasonably efficient dikes, ditches and structures to get the water over the land in such a way as to reduce the underground losses to a minimum; (d) to irrigate the ground with such a head and at such intervals as to require a minimum use of water for proper irrigation; and (e) to cultivate the irrigated ground when practicable to prevent undue losses from evaporation; in some cases possibly to govern the character of crops to be grown.

68. It is evident that the reasonable degree of perfection of each of these requirements will vary with the locality and with different changing conditions in each locality, so that the beneficial use of water is a variable.

69. Economical use of water.-Since the water supply available for irrigation in the western states is adequate for only a relatively small percentage of the entire irrigable acreage, the fundamental standard of economical use must be the financial results ${ }^{19}$ accomplished per acre-foot of water applied rather than the yield per acre irrigated. It, therefore, becomes both necessary and desirable to impress irrigators with the fact that in general the largest net profits per acre-foot of water applied are obtained, not from using excessive quantities, but from more careful use of relatively small quantities.

19 It is believed that the words "financial results" and "net profit" used in this paragraph really contradict the thought expressed in the last paragraph of the quotation, that beneficial use looks to the individual interest and economical use to the welfare of society as a whole. It is here contended that a use that has as its chief aim a large net profit to the individual is entirely different from a use that has as its chief aim the largest welfare of society as a whole. Irarge net profits increase the capacity of the individuals obtaining them to participate in the enjoyment of the aggregate wealth of the community, but they do not increase that aggregate wealth. The only use that can increase wealth is of course the use that yields a larger amount of products. The accomplishment of such a use was the ideal sought to be expressed in the paragraph dealing with economical use that was submitted to the conference by the committee to whom the subject was referred. It is not believed that the conference intended to confuse the two ideas. What it is believed was intended was rather to refrain from holding economical use that is primarily concerned with the largest possible increase of the aggregate wealth to be a practicable working plan at this stage of development. In the main the writer agrees with this contention. Such an economical use is more an ideal to have in view now, but which must ultimately be realized. 
70. In developing a more economical standard for the use of water, it should not be presumed that established rights can be limited to less water than they would carry under the accepted rule of beneficial use; yet by constantly bearing in mind that the ideal ultimately necessary must be the highest net profit per unit of water applied, irrigators may gradually be induced in many instances to obtain for themselves these results, and those undertaking the construction of new projects may be induced so to design their systems as to provide a liberal water supply during the development period with a view to ultimate development based on economic use.

7 I. In the history of irrigation in this country, there has been evident a gradual but very definite evolution in the ideas of what constitutes proper use of water. While the use of water for irrigation was at first a relatively unimportant one, its importance now overshadows all other uses, save that of domestic supply.

72 . In the course of this evolution, the doctrine of beneficial use has become established, but in future development this doctrine must in many cases merge into, or be supplanted by that of economic use.

73. The doctrine of beneficial use looks to individual imterest; that of economic use to the general welfare of society as a whole. So far as possible, water charges, systems of distribution, and regulation should be so adjusted as to make the interest of the individual water-user coincide with this public interest.

In closing this discussion it may be stated that it has not been one of the purposes of this paper specifically to attempt to indicate in just what way, or how rapidly, courts and legislatures are likely to accept the notion of economical use of water as it has been somewhat technically defined herein. The purpose has merely been to emphasize a certain principle on the basis of experimental data at hand, and in particular connection therewith to call attention to the tendency of the courts, well known to law writers, to go as far as they consistently can in requiring "the highest and greatest possible duty from the waters of the state in the interest of agriculture and other useful and beneficial purposes",- a tendency which makes the ultimate adoption in some measure of the principle of a socially economical use of water seem not at all unreasonable. That the principle will in time be a vital one 
to California is indicated by the fact that with no higher use of irrigation water than is now generally considered reasonable and economical from the individual standpoint, the irrigation waters of the state will be sufficient for the irrigation of only about one-half of the agricultural lands to which they are available that require irrigation or that irrigation would benefit. ${ }^{20}$ How rapidly the principle is likely to be adopted in the decisions of this state, for example, will depend largely on how rapidly the state fills up and on how necessary it is for people to come to California mstead of going elsewhere. It is sufficient to the ultimate adoption of the principle that the present-day tendency toward socialization of all law is more likely to grow stronger than weaker, and that a solution of this problem will be found when the interests of society require it.

That present use of water for irrigation in California is economical from even the individual standpoint to only a limited extent, is very well known, in spite of the fact that water is already used more carefully in parts of California than any where else in this country. ${ }^{21}$ That the need for making every effort to bring about a better use in this state is great, is equally clear. Where water already has a very high value, as in parts of southern California, ${ }^{22}$ financial considerations are in some cases apparently working with sufficient effect to make the individual and the social interests coincide. In such sections, however, values of water are determined from residential as well as from agricultural considerations, because so many southern California irrigated tracts are really homes rather than mainly commercial farms. In the sections that must be relied on to support the bulk of the industry of the state, however, as the great valleys, values of water will more largely be based on returns from agriculture and will be correspondingly less. In such cases it is difficult to expect a realization of the principle of a socially economical use of water as rapidly as the public good shall require without some increasing restriction by the legislature and the courts. The first step must necessarily be the $42-44$

20 U. S. Dept. Agr., Office of Experiment Stations, Bulletin 254, pp.

21 For a general statement of the character of use of water for irrigation in California see Id., pp. 45-87 and 90-95.

22 "The value of a miner's inch of canyon water varies from $\$ 1500$ to as high as $\$ 2500$ in some localities. The value of pumped water is not less than $\$ 1000$ per miner's inch." C. E. Tait in U. S. Dept. Agr., Office of Experiment Stations, Bulletin 236, p. 90. 
adoption and putting into effect in California of some such administrative water measure as other western states already have and as is provided for California in the water commission bill now on referendum. At first, very obviously, the operation of such a measure must be concerned with clearing up existing appropriation water titles, providing a more rational means for acquiring new appropriation titles than posting and recording notices and subsequent private law suits provide, and the enforcement of determined priorities by adequate administrative machinery. Along with these accomplishments, however, will go a gradual setting of standards of use, ${ }^{23}$ which can only be put into effect step by step, after full investigation and showing of the amount of water crops actually require, rather than the amount land will absorb, and the education of irrigators as to what is economical to them individually, and of the people generally as to what the general public good demands.

FRANK ADAMS.

Berkeley, California.

23 In Nichols v. Hufford (1913), 133 Pac. 1084, the Wyoming Supreme Court found, in substance, that as to an appropriation made prior to the enactment of the statutes regulating the use of water now in force, the board of water control and the courts may properly limit the right of any appropriator to the amount of water reasonably necessary when properly applied. 